\title{
Survei Nyamuk Culex spp. sebagai Vektor Filariasis di Desa Cisayong, Kecamatan Cisayong, Kabupaten Tasikmalaya
}

\author{
Wulan Dwi Portunasari ${ }^{1}$, Endang Srimurni Kusmintarsih ${ }^{1}$, Edy Riwidiharso ${ }^{1}$ \\ ${ }^{1}$ Fakultas Biologi, UniversitasJenderal Soedirman \\ Email :wulanportun@gmail.com
}

\begin{abstract}
Lymphatic filariasis is a disease caused by the filarial worm Wuchereria brancofti, Brugia malayi, and Brugia timori that attack lymph and lymph nodes. Cx. quinquefasciatus is a vector of filarial bancroftiin urban area. Subdistrict Cisayong as endemic filariasis area with microfilaria rate in $>1 \%$. Elimination of Filariasis in Indonesia was done in two methods such as filariasis mass drug administration in endemic areas and vectorcontrol. Vector control and potential transmission of filariasis needs some information including infection rate, parity rate and density of Culex larvae. The purpose of research are to observe the spesies of Culex mosquitoes, infection rate, parousitas, and density of Culex mosquito larvae. The method is a survey method using cluster sampling method. The cluster in this research are 39 RT in Cisayong village. Mosquitoes was catched from 9 groups (RT) which is elected. Sampling was conducted in the night at 18:00 to 00:00 pm. The results shows that the spesiesof Culex were catched in Cisayong including Cx. quinquefasciatus, Cx. hutchinsoni, Cx. sitiens, Cx. vishnui, Cx. pseudovishnui, Cx. tritaeniorinchus, dan Cx gelidus, infection rate is $0 \%$, while of parousitas $C x$. quinquefasciatus $66 \%, C x$. hutchinsoni $17 \%$, Cx. sitiens $68 \%$, Cx. vishnui $55 \%$, Cx. pseudovishnui $21 \%$, Cx. tritaeniorinchus $53 \%$, and Cx. gelidus $54 \%$ respectively. The density of Culex sp. larvae is 3,38/dipper.
\end{abstract}

Key Words : Culex, Filariasis Infection Rate, Parousitas, Cisayong.

\begin{abstract}
Abstrak
Filariasis limfatik merupakan penyakit disebabkan oleh cacing filaria Wuchereria brancofti, Brugia malayi, dan Brugia timori yang menyerang saluran dan kelenjar getah bening. Cx. quinquefasciatus merupakan vektor filariasis bancrofti di daerah urban. Kecamatan Cisayong endemis filariasis dengan Microfilaria rate $>1 \%$. Eliminasi filariasis di Indonesia ditetapkan dua pilar kegiatan yaitu pemberian obat massal pencegahan filariasis (POMP filariasis) di daerah endemis dan pengendalian vektor. Pengendalian vektor dan potensi vektor dalam penularan filariasis dapat diketahui melalui berbagai hal diantaranya dengan mengetahui spesies Culex, angka infeksi, parousitas dan kepadatan larva Culex.Tujuan penelitian yaitu mengetahui spesies nyamuk Culex, infection rate, parousitas, dan kepadatan larva nyamuk Culex. Metode yang digunakan dalam penelitian ini yaitu metode survei dengan teknik cluster sampling. Kelompok (Cluster) dalam penelitian ini yaitu RT berjumlah 39 RT yang ada di Desa Cisayong. Penangkapan sampel nyamuk dilakukan di 9 kelompok (RT) yang terpilih. Pengambilan sampel dilakukan pada malam hari pukul 18.00-00.00 WIB. Hasil penelitan menujukkan bahwa spesies Culex yang ditangkap di Desa Cisayog diantaranya Cx. quinquefasciatus, Cx. hutchinsoni , Cx. sitiens , Cx. vishnui , Cx. pseudovishnui , Cx. tritaeniorhynchus dan Cx. gelidus, infection rate $0 \%$, sementara itu, parousitasCx. quinquefasciatus $66 \%$, Cx. hutchinsoni $17 \%$, Cx. sitiens 68\%, Cx. vishnui 55\%, Cx. pseudovishnui $21 \%$, Cx. tritaeniorhynchus 53\%, dan Cx. gelidus 54\%. Kepadatan larva Culex sp. yaitu 3,38/cidukan.
\end{abstract}

Kata kunci :Culex, Filariasis Infection Rate, Parousitas, Cisayong.

\section{Pendahuluan}

Filariasis limfatik merupakan salah satu penyakit menular yang masih menjadi masalah kesehatan di dunia. Filariasis limfatik disebabkan oleh cacing filaria Wuchereria bancrofti, Brugia malayi dan Brugia timori yang menyerang saluran dan kelenjar getah bening serta ditularkan oleh berbagai jenis nyamuk (Kemenkes RI, 2010). Penyakit ini tidak mematikan namun menimbulkan sakit secara fisik yang bersifat kronis dan kecacatan yang permanen sehingga menurunkan aktivitas, produktivitas penderita dan menjadi beban sosial keluarga (Srimurni et al., 2008).
Selain itu, filariasis dapat menimbulkan dampak ekonomi dan dampak mental secara psikologis (WHO, 1997).

Negara endemik filariasis terbanyak di dunia setelah India yaitu Indonesia dan ketiga terbanyak adalah Nigeria (Okona et al., 2010). Jumlah Provinsi di Indonesia yang melaporkan kasus filariasis dari tahun ke tahun terus bertambah. Jumlah penderita kronis filariasis di Jawa Barat sampai Juni 2013 sebanyak 886 orang dengan jumlah kematian 51 orang yang tersebar di 25 kabupaten/kota, 135 kecamatan dan 221 desa/kelurahan. Sedangkan daerah endemis filariasis sebanyak 11 Kabupaten/kota 
dengan Microfilaria Rate (Mf Rate) 1,0\%-5,25\% diantaranya Kabupaten Subang, Karawang, Purwakarta, Bekasi, Bogor, Tasikmalaya, Kuningan, Bandung, Kota Bekasi, kota Bogor, dan Kota Depok. Kasus filariasis kronis dan kematian tertinggi sampai Juni tahun 2013 yaitu di Kabupaten Sukabumi, kemudian Kabupaten Bekasi dan Kabupaten Tasikmalaya berada di urutan ketiga tertinggi di Provinsi Jawa Barat (Astuti et al., 2014).

Kasus filariasis di Tasikmalaya tersebar di 27 kecamatan, sedangkan penderita terbanyak dilaporkan di Kecamatan Tanjungjaya, Cisayong, Ciawi, Sukaratu dan Cipatujah. Menurut informasi dari Puskesmas Cisayong, hasil survei darah jari pada tahun 2006 di Kecamatan Cisayong, dari 500 sampel yang diperiksa 8 diantaranya positif mikrofilaria. Hasil tersebut menunjukkan bahwa Kecamatan Cisayong merupakan salah satu kecamatan endemis filariasis dengan Microfilaria rate $>1 \%$. Pengobatan massal telah dilakukan pada tahun 2007 di wilayah Kecamatan Cisayong, namun demikian pengobatan sempat berhenti pada tahun 2008 dan dilanjutkan kembali pada tahun 2009-2013. Wilayah Kecamatan Cisayong terdiri atas 13 desa, dengan penderita filariasis kronis tercatat sebanyak empat orang yang tersebar di Desa Cisayong, Santanamekar, Sukajadi dan Sukaraharja.

Eliminasi filariasis di Indonesia ditetapkan dua pilar kegiatan yaitu memutuskan rantai penularan melalui pemberian obat massal pencegahan filariasis (POMP filariasis) di daerah endemis dengan obat Diethyl Carbamazine Citrate (DEC) dikombinasikan dengan albendazol sekali setahun selama 5-10 tahun. Selain itu, dilakukan pengendalian vektor dengan cara meminimalkan habitat perkembangan vektor, menurunkan kepadatan vektor (larva dan dewasa), dan mengurangi kontak antara vektor dan manusia (Astuti et al., 2014). Pengetahuan mengenai bionomik vektor sangat diperlukan dalam pengendalian vektor. Usaha pengendalian vektor akan maksimal, apabila ada kecocokan antara vektor yang menjadi target dengan metode pengendalian yang diterapkan (Syachrial et al., 2005).

Menurut Ramadhani (2009), jenis nyamuk Culex quinquefasciatus dikenal sebagai vektor filariasis Wuchereria bancrofti. Nyamuk Culex aktif pada malam hari dengan jarak terbang maksimum $5 \mathrm{~km}$ dari tempat perindukan (Webb et al., 2016). Nyamuk betina menghisap darah untuk proses pematangan telur dan kemudian meletakkan telur pada tempat yang disukainya. Waktu yang diperlukan untuk mematangkan telur dimulai dari menghisap darah sampai mengeluarkan telur biasanya 3-4 hari yang disebut dengan siklus gonotropik. Jumlah siklus gonotropik dapat ditentukan dengan memeriksa ovariumnya. Satu siklus gonotropik sama dengan satu parous.
(WHO, 2013a). Parousitas merupakan besarnya angka nyamuk yang pernah bertelur dari semua nyamuk yang dibedah, baik parous maupun nulliparous (Yahya, 2002) dengan parousitas tersebut dapat memperkirakan umur nyamuk (Dharmawan, 1993).

Menurut Natadisastra \& Ridad (2005), jika nyamuk menghisap darah yang terinfeksi mikrofilaria maka mikrofilaria akan ikut terhisap bersama darah menuju usus tengah, kemudian melepaskan selubungnya. Setelah melepaskan selubungnya, Cacing mikrofilaria bergerak menuju otot dada nyamuk untuk berkembang menjadi larva tahap pertama (L1), larva tahap kedua (L2) dan larva tahap ketiga (L3). Banyaknya nyamuk yang terinfeksi oleh larva mikrofilaria baik L1, L2 maupun $\mathrm{L} 3$ dapat dihitung dengan infection rate (WHO, 2013a).

Penelitian ini dilakukan dengan tujuan untuk Mengetahui spesies, angka infeksi, parousitas, dan kepadatan larva nyamuk Culex yang ditangkap di Desa Cisayong, Kecamatan Cisayong, Kabupaten Tasikmalaya.

Hasil penelitian ini diharapkan dapat bermanfaat untuk pengendalian vektor filariasis khususnya di Cisayong, Kabupaten Tasikmalaya, Jawa Barat.

\section{Metode}

Penelitian ini dilaksanakan di Desa Cisayong, Kecamatan Cisayong, Kabupaten Tasikmalaya.Timur selama 3 bulan pada bulan Juli-September 2016.

Bahan yang digunakan adalah nyamuk Culex, air gula, larutan Natrium Clorida $(\mathrm{NaCl})$, dan diethyl eter. Alat-alat yang digunakan adalah paper cup, lampu senter, aspirator, kapas, kain organdi, karet gelang, mikroskop stereo, jarum bedah, pipet, pinset, cawan petri, object glass, cover glass, kertas label, buku identifikasi nyamuk, cidukan, buku tulis, bolpoin, dan kamera.

Metode yang digunakan dalam penelitian ini yaitu metode survei dengan teknik cluster sampling. Kelompok (cluster) dalam penelitian ini yaitu setiap RT di Desa Cisayong yang berjumlah 39 RT. Tempat pengambilan sampel dilakukan di 9 RT yang dipilih secara acak. Penangkapan sampel nyamuk dilakukan pada malam hari pukul 18.00-00.00 WIB dan pengambilan larva dilakukan pada siang hari.

Penelitian ini meliputi kegiatan kerja sebagai berikut :

\section{Penangkapan Nyamuk}

Penangkapan nyamuk dilakukan di luar rumah (outdoor collection) di sekitar kandang ternak dengan menggunakan aspirator dan diterangi lampu senter. Nyamuk yang ditangkap dimasukkan ke dalam paper cup yang bertutup 
kain kasa, diikat dengan karet dan diberi label (tanggal, lokasi dan nama kolektor). Kain kasa diberi lubang dan lubang tersebut ditutup dengan kapas yang sudah diberi air gula (WHO, 2013b).

\section{Identifikasi Nyamuk Culex}

Nyamuk yang diperoleh dimatikan dengan cara dibius menggunakan diethyl eter, kemudian dipindahkan pada cawan petri yang diletakkan di bawah mikroskop stereo dan diidentifikasi dari tingkat genus menggunakan kunci identifikasi dari Mattingly (1973) dan identifikasi spesies menggunakan kunci identifikasi nyamuk Culex dari Depkes RI (2008).

\section{Pemeriksaan parousitas}

Pemeriksaan parousitas dilakukan dengan cara membedah ovarium nyamuk. Nyamuk yang telah diidentifikasi diletakkan pada cawan petri, sayap dan kaki dipisahkan dari tubuhnya, kemudian tubuh nyamuk diletakkan di atas object glass dan ditetesi $\mathrm{NaCl}$ fisiologis. Setelah itu, dilakukan pembedahan menggunakan jarum bedah. Pembedahan dilakukan secara mikroskopis dengan menggunakan mikroskop stereo. Jarum bedah pada tangan kiri menekan bagian dada dan jarum bedah pada tangan kanan menekan segmen ke-VII lalu digeser secara perlahan-lahan ke arah kanan sampai isi abdomen dan ovarium tertarik ke luar. Ovarium diletakkan pada object glass yang baru diberi akuades untuk melihat trakeolar (tracheolus skein) menggunakan mikroskop cahaya dengan perbesaran 40x10 (WHO, 1975).

\section{Pemeriksaan Larva Mikrofilaria di dalam Tubuh Nyamuk}

Nyamuk yang telah dibedah ovariumnya, bagian kepala dipisahkan dengan toraks, sehingga tubuhnya menjadi tiga bagian yaitu kepala, toraks dan abdomen. Tiap-tiap bagian tubuh nyamuk tersebut ditetesi larutan garam fisiologis kemudian bagian kepala, toraks dan abdomen dibedah untuk diamati keberadaanlarva microfilaria menggunakan mikroskop cahaya dengan perbesaran 40x10 (WHO, 2013a).

\section{Penangkapan Larva Nyamuk Culex}

Larva nyamuk Culex diambil menggunakan dipper (cidukan) dari tempat perindukan (selokan dan genangan air).kemudian larva yang tertangkap dipindahkan ke botol sampel menggunakan pipet.

\section{IdentifikasiLarva Nyamuk Culex}

Larva nyamuk yang didapatkan dipindahkan pada object glass dan diamati menggunakan mikroskop stereo serta diidentifikasi sampai tingkat genus menggunakan buku identifikasi dari Depkes RI (2008).

\section{Analisis Data}

Angka infeksi $=\frac{\text { jumlah nyamuk positif larva mikrofilaria }}{\text { jumlah nyamuk yang dibedah }} \times 100$
Parousitas $=\frac{\text { jumlah nyamuk parous }}{\text { jumlah nyamuk dibedah (parous }+ \text { nulliparous) }} \times 100$ Kepadatan Larva $=\frac{\text { jumlah jentik ditangkap per genus }}{\text { jumlah cidukan jentik }}$

\section{Hasil dan Pembahasan}

Sampel nyamuk Culex yang diperoleh di sembilan tempat sampling (RT) sebanyak 357 ekor. Nyamuk Culex yang ditangkap tubuhnya berwarna cokelat kehitam-hitaman, ujung abdomen tumpul, palpus lebih pendek dari proboscis, dan sayap berwarna gelap (Gambar 1.). Berdasarkan identifikasi ditemukan 7 spesies Culex yaitu $C x$. quinquefasciatus, $C x$. hutchinsoni, $C x$. sitienss, $C x$. vishnui, $C x$. pseudovishnui, $C x$. tritaeniorinchus, dan $C x$ gelidus.Ciri utama pada $C x$. quinquefasciatus yaitu pleuron berwarna pucat, sedangkan $C x$. hutchinsoni pleuron berwarna gelap kehitam-hitaman, permukaan anterior femur kaki tengah $C x$. sitiens berbercak berupa sisik-sisik cokelat dan putih, $C x$. vishnui memiliki permukaan anterior femur kaki tengah sebagian besar gelap dan tidak memiliki sisik, $C x$. pseudovishnui memiliki vertex dengan sisik-sisik berwarna kekuning-kuningan, $C x$. tritaeniorhynchus bagian ventral proboscis ke pangkal dengan bercak pucat dan Cx. gelidus memiliki scutum berwarna putih keperakan.

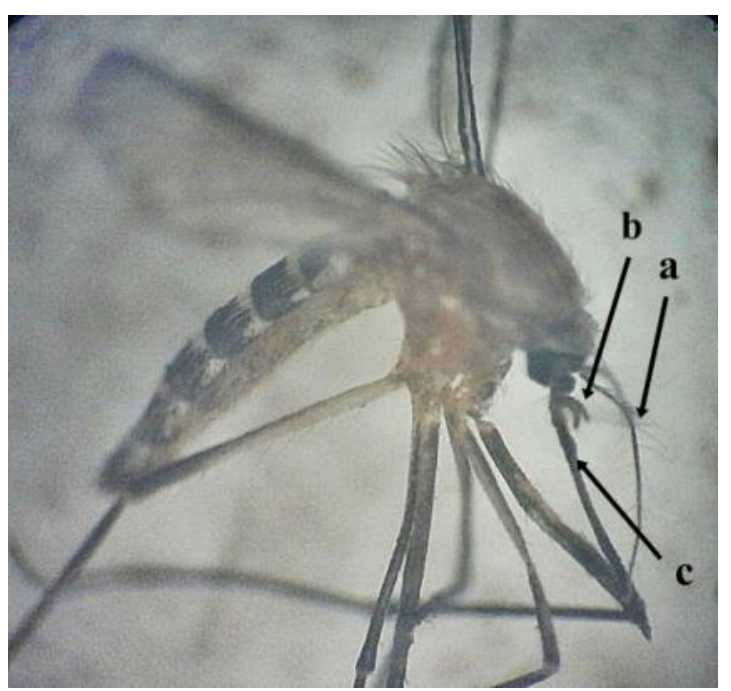

Gambar 1. Morfologi Nyamuk Culex. (a) antena, (b) palpus, (c) probosi

Hasil pembedahan tubuh nyamuk Culex menunjukkan dari 357 nyamuk yang dibedah tidak 
ditemukan larva mikrofilaria sehingga angka infeksinya (infection rate) $0 \%$ (Tabel.1)

Tabel 1. Infection Rate Nyamuk Culex yang ditangkap dengan umpan resting kandang di Desa Cisayong, Kabupaten Tasikmalaya

\begin{tabular}{lcc}
\hline Spesies & $\begin{array}{c}\text { Jumlah yang } \\
\text { Ditangkap }\end{array}$ & $\begin{array}{c}\text { Infection } \\
\text { Rate (\%) }\end{array}$ \\
\hline Cx. & 107 & 0 \\
quinquefasciatus & 29 & 0 \\
Cx. hutchinsoni & 92 & 0 \\
Cx. sitiens & 76 & 0 \\
Cx. vishnui & 14 & 0 \\
Cx. pseudovishnui & 28 & 0 \\
Cx. tritaeniorinchus & 11 & 0 \\
Cx. gelidus & 357 & 0 \\
\hline Total &
\end{tabular}

Hal ini disebabkan di Desa Cisayong telah dilakukan pengobatan masal (POMP filariasis) satu tahun sekali selama lima kali dari tahun 2007-2013. Keadaan ini mengindikasikan bahwa sudah tidak terjadi transmisi penularan filariasis limfatik di Desa Cisayong. Berdasarkan penelitian Hasmiwati \& Nurhayati (2009) di Kenagarian Mungo, menunjukkan bahwa tidak ditemukannya larva mikrofilaria pada nyamuk dikarenakan di tempat tersebut sedang dilakukan pengobatan masal. Pengobatan dilakukan dengan DEC (Diethyl Carbamazin), albendazol dan parasetamol sebanyak 3x dari tahun 2005 sampai tahun 2008, sehingga kemungkinan penularan baru filaria tidak terjadi lagi karena mikrofilaria pada tubuh manusia telah mati.

Tidak ditemukannya larva mikrofilaria dalam tubuh nyamuk dipengaruhi oleh beberapa faktor, diantaranya kemampuan nyamuk untuk menghisap darah terbatas, sehingga peluang larva mikrofilaria yang ikut terhisap kecil. Faktor lain yang mempengaruhi tidak ditemukannya larva microfilaria dalam tubuh nyamuk yaitu kepadatan larva mikrofilaria dalam tubuh manusia rendah sehingga transmisi mikrofilaria ke tubuh nyamuk tidak terjadi (Santoso et al., 2015). Menurut Sumarni dan Soeyoko (1998), diperlukan sekitar 1-3 $\mathrm{mf} / \mathrm{mm}^{3}$ kepadatan mikrofilaria dalam darah manusia agar transmisi dapat terjadi secara optimal.

Faktor perilaku nyamuk dan cacing filaria di dalam tubuh manusia juga berperan dalam transmisi filariasis. Perilaku mikrofilaria bergerak aktif ke darah tepi harus sesuai dengan perilaku menggigit nyamuk vektor. Mikrofilaria juga harus dapat bergerak aktif dari darah viseral ke darah tepi pada waktunya atau dengan perilaku yang tepat sehingga dapat menginfeksi nyamuk vektor. Jika nyamuk menghisap darah sebelum larva mikrofilaria muncul ke darah tepi, maka transmisi tidak terjadi dari tubuh manusia ke nyamuk (Santoso et al., 2015).

Transmisi filariasia terjadi melalui gigitan nyamuk. Nyamuk yang telah menghisap darah bisa ditunjukan dengan parousitas. Parous atau nuliparous dari nyamuk diketahui dengan melakukan pembedahan pada ovarium dan dilihat trakeolarnya (Gambar 2.)

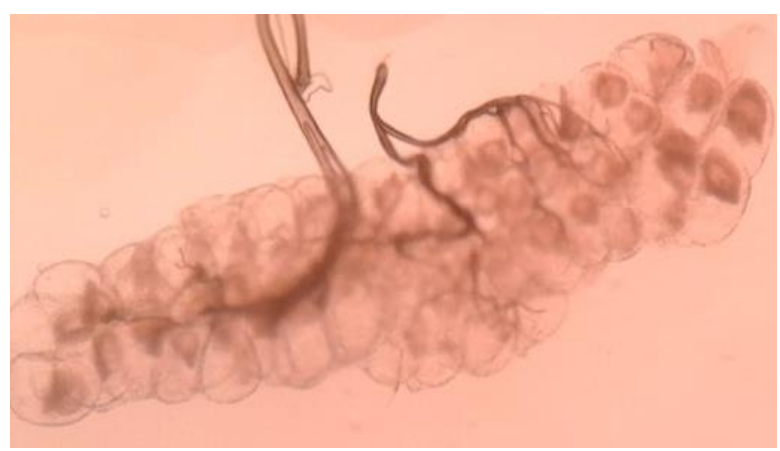

Gambar 2. Ovarium nyamuk Culex (perbesaran $5 \times 10)$

Jika trakeolarnya sudah terurai maka dikatakan parous, sedangkan jika trakeolarnya masih menggulung maka ovarium tersebut nulliparous (Gambar 3.). Menurut Andreadis, et al. (2010), nuliparous mudah diamati dengan adanya trakeolar yang menggulung atau sedikit longgar diujungnya. Sedangkan ovarium parous mempunyai trakeolar yang terurai, jelas dan lurus. Pengamatan parousitas pada nyamuk Culex sp. diperoleh hasil $57 \%$ dengan parousitas tertinggi pada nyamuk $C x$. sitiens ebesar $68 \%$, kemudian diikuti berturut-turut oleh nyamuk $C x$. quinquefasciatus $66 \%, C x$. vishnui $55 \%, C x$ gelidus 54\%, Cx. tritaeniorinchus 53\%, Cx. pseudovishnui $21 \%$, dan parousitas terendah $C x$. hutchinsoni $17 \%$ (Tabel 2.). Parousitas menunjukkan bahwa nyamuk sudah pernah menghisap darah dan pernah bertelur. Hal ini menunjukkan populasi nyamuk $C x$. sitiens, $C x$. quinquefasciatus, $C x$. vishnui, $C x$. gelidus, dan $C x$. tritaeniorhynchus di lokasi penelitian sebagian besar sudah menghisap darah dibandingkan nyamuk lain yang ditangkap.

Menurut Cahyati\& Suharyo (2006), Jika hasil survei entomologi di suatu wilayah memiliki parousitas yang rendah, maka populasi nyamuk sebagian besar masih muda. Sedangkan jika parousitas tinggi, maka populasi nyamuk di wilayah tersebut sudah tua. Nyamuk yang parous menunjukkan nyamuk tersebut telah menghisap darah hospes sehingga berpotensi menjadi vektor penyakit.Semakin tinggi parousitas nyamuk, maka semakin tinggi pula potensi penularan. 

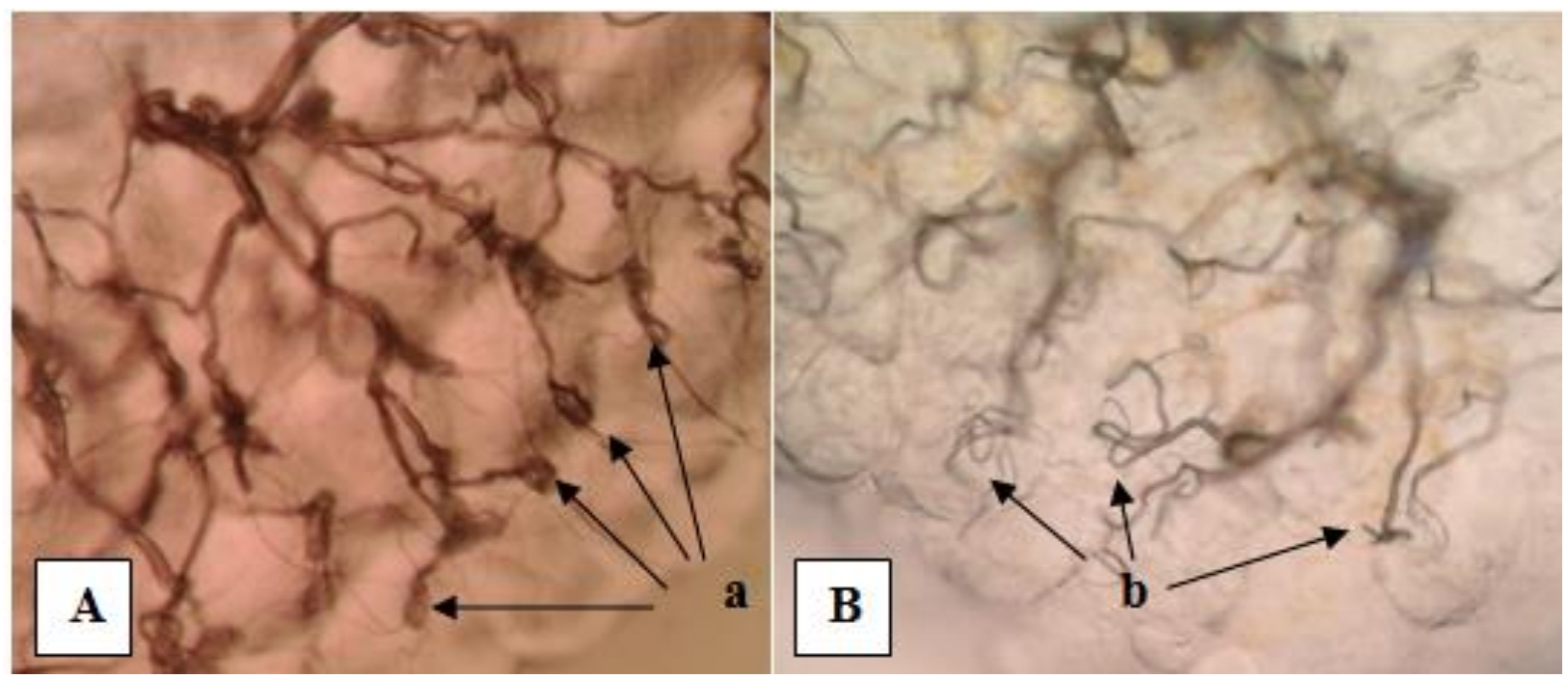

Gambar 3. A. Ovarium parous (a) trakeolar menggulung, B. ovarium nuliparous (b) trakeolar terurai (perbesaran 40x10).

Tabel 2. Parousitas nyamuk Culex per spesies yang ditangkap dengan umpan resting kandang di Desa Cisayong

\begin{tabular}{|c|c|c|c|}
\hline Spesies & $\begin{array}{c}\text { Nyamuk } \\
\text { yang } \\
\text { dibedah }\end{array}$ & Parous & $\begin{array}{l}\text { Parity } \\
\text { Rate } \\
(\%)\end{array}$ \\
\hline $\begin{array}{l}\text { Cx. } \\
\text { quinquefasciatus }\end{array}$ & 107 & 71 & 66 \\
\hline Cx. hutchinsoni & 29 & 5 & 17 \\
\hline Cx. sitiens & 92 & 63 & 68 \\
\hline Cx. vishnui & 76 & 42 & 55 \\
\hline $\begin{array}{l}\text { Cx. } \\
\text { pseudovishnui }\end{array}$ & 14 & 3 & 21 \\
\hline $\begin{array}{l}\text { Cx. } \\
\text { tritaeniorhynchus }\end{array}$ & 28 & 15 & 53 \\
\hline Cx gelidus & 11 & 6 & 54 \\
\hline Total & 357 & 205 & \\
\hline
\end{tabular}

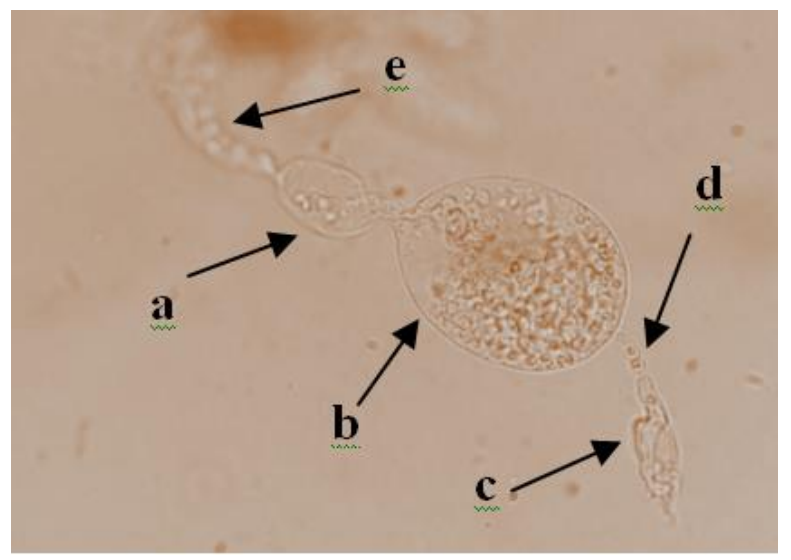

Gambar 4. Folikel pada ovarium parous nyamuk Culex (a) folikel sekunder, (b) folikel primer, (c) 1-dilatasi, (d) pedikel, (e) selubung ovariolar (perbesaran $40 \times 10)$.
Hasil penelitian terhadap nyamuk parous diperoleh dilatasi 1-3 (Gambar 3).dilatasi yang terbentuk dapat digunakan untuk memperkirakan umur nyamuk (Wahyuningsih et al., 2004). Dilatasi terbentuk setelah nyamuk bertelur, satu dilatasi sama dengan satu siklus gonotropik. Menurut Mahmood et al. (1998), satu parous mempunyai satu dilatasi yang akan terbentuk 24 jam setelah oviposisi.Satu siklus gonotropik berkisar antara 3-4 hari (WHO, 2013a). Lama siklus gonotropik tergantung dari jenis nyamuk dan ketinggian tempat. Menurut penelitian yang dilakukan oleh Pramastuti \& Martini (2012) di Wonosobo, siklus gonotropik nyamuk Aedes albopictus (3-7 hari) rata-rata 5 hari dan Ae. aegepty (3-5 hari) rata-rata 4 hari. Begitu juga penelitian yang dilakukan oleh Mintarsih et al (1996), siklus gonotropik nyamuk Ae. aegeptydi Salatiga 3-7 hari dan di Semarang 3-4 hari. Jika siklus gonotropik diasumsikan 4 hari maka ratarata nyamuk yang ditangkap di Desa Cisayong berkisar antara 4-12 hari.

Nyamuk dapat menjadi vektor filariasis jika mempunyai umur yang cukup lama sehingga parasit dapat menyelesaikan siklus hidupnya di dalam tubuh nyamuk. jika umur nyamuk lebih panjang dari umur parasit maka otomatis parasit dapat berkembang sampai menjadi larva infektif untuk menularkannya. Menurut WHO (2013b), cacing filaria berkembang dari mikrofilaria sampai menjadi L3 pada tubuh nyamuk selama 10-13 hari, maka untuk menjadi vektor filariasis, nyamuk harus berumur lebih dari 13 hari. Semakin panjang umur nyamuk, semakin besar kemungkinan untuk menjadi penular atau vektor (Ramadhani \& Bondan, 2015). 


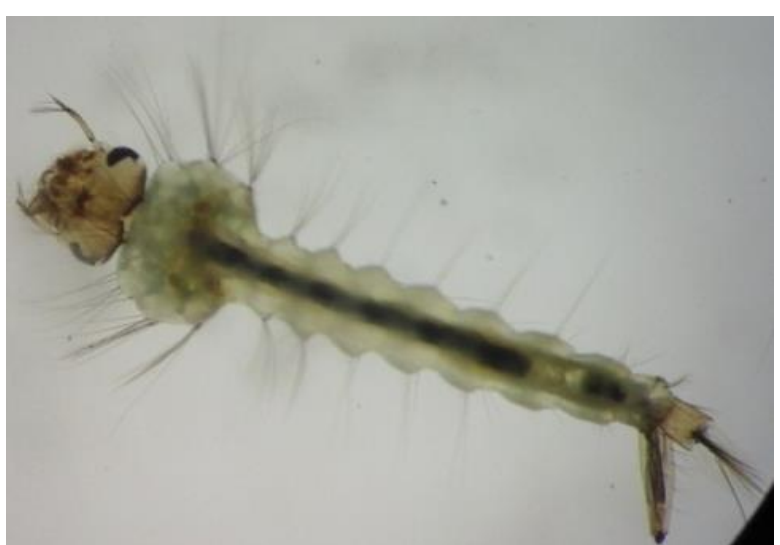

Gambar 5. Larva nyamuk Culex yang ditemukan di Desa Cisayong

Nyamuk mempunyai metamorfosis sempurna yaitu telur, larva, pupa kemudian menjadi dewasa. Telur Culex berwarna coklat, panjang, silinder vertikal, bergabung membentuk seperti rakit pada permukaan air yang tenang (Service, 2002). Telur berkembang menjadi larva dan larva mendapat makanan dari bahan-bahan organik yang terdapat di dalam air. Larva nyamuk bernafas dengan siphon. Larva nyamuk Culex memiliki siphon yang agak ramping dan lebih panjang dibandingkan dengan siphon larva nyamuk Aedes dengan kumpulan bulu lebih dari satu. Kepala larva nyamuk Culex mempunyai lebar hampir sama dengan lebar toraks (Gambar 4).

Tabel 4.3. Kepadatan larva nyamuk Culex sp.yang ditemukan di Desa Cisayong

\begin{tabular}{lccc}
\hline Genus & $\begin{array}{c}\text { Jumlah } \\
\text { larva yang } \\
\text { ditemukan } \\
\text { (ekor) }\end{array}$ & $\begin{array}{c}\text { Jumlah } \\
\text { cidukan } \\
\text { (kali) }\end{array}$ & $\begin{array}{c}\text { Kepadatan } \\
\text { (per cidukan) }\end{array}$ \\
\hline Culex & 27 & $8 \times$ & $3,38 \pm \sqrt{ } 1,84$ \\
\hline
\end{tabular}

Larva nyamuk Culex yang ditemukan di Desa Cisayong dengan metode dipping (cidukan) pada tempat perindukan diperoleh 27 ekor dari 8 kali cidukan sehingga kepadatannya yaitu 3,38 \pm $\sqrt{1,84}$ (Tabel 4.3). Kepadatan larva pada musim hujan dapat menurun dikarenakan larva pada tempat perindukan akan terbawa arus. Hasil

\section{Daftar Referensi}

Andreadis, T.G., Philip, M.A., \& Waheed, I. B. 2010. Studies On Hibernating Populations Of Culex Pipiens From A West Nile Virus Endemic Focus In New York City: Parousitass And Isolation Of West Nile Virus. Journal Of The American Mosquito Control Association., 26(3), Pp. 57-264. pengamatan larva nyamuk Culex di desa Cisayong ditemukan di kolam ikan yang sudah tidak dipakai. Menurut Valiant et al. (2010) nyamuk Culex $s p$. lebih menyukai air yang kotor seperti genangan air kotor, limbah pembuangan kamar mandi, got (selokan), dan sungai yang penuh sampah. Penelitian yang dilakukan oleh Wetzel et al. (2015), nyamuk Culex ditemukan di drainase saluran limbah, drainase yang terkontaminasi limbah, genangan air banjir, air mancur di taman kota, dan ember terbuka yang berisi air hujan. Webb et al. (2016) menambahkan, banyak larva nyamukCulex yang ditemukan di lahan basah air tawar, untuk irigasi pertanian, saluran limbah peternakan, dan selokan pinggir jalan. Nyamuk tersebut cepat beradaptasi dengan habitatnya sehingga memungkinkan dapat berkembang pesat untuk menghasilkan telur yang akan berkembang menjadi larva.

\section{Simpulan}

Berdasarkan hasil dan pembahasan, maka dapat disimpulkan bahwa :

1. Nyamuk Culex yang ditangkap di Desa Cisayong yaitu $C x$. quinquefasciatus, $C x$. hutchinsoni, Cx. sitiens, Cx. vishnui, $C x$. pseudovishnui, Cx. tritaeniorinchus, dan $C x$ gelidus.

2. Nyamuk Culex yang ditangkap di Desa Cisayong tidak ada yang mengandung cacing filarial.

3. Parousitas nyamuk Culex sp. di Desa Cisayong cukup tinggi dan parousitas tertinggi pada Cx.sitiens.

4. Kepadatan larva nyamuk Culex di Desa Cisayong relative rendah.

\section{Ucapan Terimakasih}

Terimakasih kepada H. Oki Zulkifli, M.Epid. selaku Kepala Dinas Kesehatan Kabupaten Tasikmalaya yang telah memberikan izin penelitian dan pengamatan di laboratorium Dinkes serta terimakasih kepada masyarakat Desa Cisayong yang telah membantu dalam pelaksanaan penelitian.

Astuti., E.P, Mara, I. M., Umar., R \& Tri., W. 2014. Mengenal Filariasis di Jawa Barat. Yogyakarta : PT. Kanisius.

Cahyati, W. H., \& Suharyo. 2006. Dinamika Aedes Aegepty sebagai vektor penyakit. Kesmas. 2(1), pp. 1-11.

Dharmawan, R. 1993. Metoda Identifikasi Spesies Kembar Nyamuk Anopheles.Surakarta : Sebelas Maret University Press. 
Hasmiwati \& Nurhayati. 2009.Kajian nyamuk vektor $\mathrm{Di}$ daerah endemik filariasis $\mathrm{Di}$ kenagarian mungo,Kabupaten Lima Puluh Kota. Jurnal Kesehatan Masyarakat. 2 (3), pp. 58-61.

Kementerian Kesehatan RI. 2010. Buletin Jendela Epidemiologi Filariasis di Indonesia. Volume 1. Jakarta : Pusat data dan Surveilans Epidemiologi Kementerian Kesehatan RI.

Mahmood, F., \& Wayne, J.C. 1998. Ovarian Development and Parity Determination in Culiseta melanura (Diptera: Culicidae). Journal Of Medical Entomology. 35(6), pp. 980-988.

Natadisastra, D \& Ridad, A. 2005. Parasitologi Kedokteran : Ditinjau dari organ tubuh yang diserang. Jakarta : Buku Kedokteran ECG.

Okona., O.E, Iboha., C.I. \& Oparab., 2010. Bancroftian Filariasis Among The Mbembe People Of Cross River State Nigeria. Journal Vector Borne Diseasse. 47, pp.9196.

Pramestuti, N., \& Martini. 2012. Perbedaan Siklus Gonotropik Dan Peluang Hidup Aedes Sp. Di Kabupaten Wonosobo. Jumal Fkologi Kesehatan. 11(3), pp. 194- 201.

Ramadhani, T. 2009. Komposisi Spesies dan Dominasi Nyamuk Culex Di Daerah Endemis Filariasis Limfatik Di Kelurahan Pabean Kota Pekalongan. Balaba. 5(2), pp.7-11.

Ramadhani, T., \& Bondan, F. W. 2015. Keanekaragaman dan Dominasi Nyamuk di Daerah Endemis Filariasis Limfatik, Kota Pekalongan. Jurnal Vektor Penyakit. 9(1), pp. 1-8.

Santoso., Yahya., Nungki, H. S., \& Katarina, S. R. 2015. Deteksi Mikrofilaria Brugia Malayi pada Nyamuk Mansonia Spp dengan Pembedahan dan Metode PCR Di Kabupaten Tanjung Jabung Timur. ASPIRATOR. 7(1), pp. pp. 29-35.

Service, M. W. 2002. Medical entomology for students. 2nd ed. Cambridge : Cambridge Publisher.

Srimurni, E., Soeyoko.,\& Sri, S., 2008. Pengobatan Filariasis dengan Target Utama Endosymbiont Bakteri Wolbachia s. Majalah Kedokteran Indonesia. 58(10), pp. 377-382.

Sumarni, S,.\& Soeyoko. 1998. Filariasis malayi di Wilayah Puskesmas Cempaka Mulia, Sampit, Kalimantan Tengah (Beberapa Faktor yang Mempengaruhi Penularannya).
Jurnal Berita Kedokteran Masyarakat. 15(3), pp. 145-8.

Syachrial, Z., Santi, M., Ririh.,,\& Huda. (2005) Populasi NyamukDewasa Di Daerah Endemis Filariasis Studi Di Desa Empat Kecamatan Simpang Empat Kabupaten Banjar Tahun 2004. JurnalKesehatan Lingkungan,. 2(1), pp. 85-96

Valiant, M., Sylvia, S., \& Susy, T. 2010. Efek Infusa Daun Pepaya (Carica papayaL.) terhadap Larva Nyamuk Culex sp. JKM. 9(2), pp. 155-160.

Webb, C., Stephen, D., \& Richard, R. 2016. A Guide to Mosquitoes of Australia. Clayton south CSIRO publishing. https://books.google.co.id/books? id=XHaA CwAAQBAJ\&pg $=P R 2 \& d q=a+$ guide + to + mo squitoes + of + australia\&hl=id\&sa $=X \& v e d=0 a$ hUKEwirnJil--

jPAhVEK48KHU2hAicQ6wEIHTAA\#v=onep age $\& q=a \% 20$ guide $\% 20$ to $\% 20$ mosquitoes $\%$ 20of\%20australia\&f=false. Diakses tanggal 20 Oktober 2016.

Weitzel, T., Piotr, J., Katarzyna, R., Elzbieta, L., \& Norbert, B. 2015. Culex pipiens and Culex torrentium (Culicidae) in Wrocław area (Poland): occurrence and breeding site preferences of mosquito vectors. Parasitol Res. 114, pp : 289-295.

WHO, 1975. Manual on Practical Entomology in Malaria II : Methods and Techniques. Geneva.

WHO, 1997. Lympatic Filariasis Today : Reason for Hope. Geneva.

WHO, 2013a. Global Programe To Eliminate Lymphatic Filariasis:Practical Entomologi. Geneva.

Yahya \& Santoso. 2013. Studi Endemisitas Filariasis $\mathrm{Di}$ Wilayah Kecamatan Pemayung, Kabupaten Batanghari Pasca Pengobatan Massal Tahap III. Buletin Penelitian Kesehatan. 41(1), pp.18-2. 